\title{
Like mother, like child: investigating perinatal and maternal health stress in post-medieval London
}

Book or Report Section

Accepted Version

Hodson, C. M. ORCID: https://orcid.org/0000-0002-3408-2871

and Gowland, R. (2020) Like mother, like child: investigating perinatal and maternal health stress in post-medieval London. In: Gowland, R. and Halcrow, S. (eds.) The Mother-Infant Nexus in Anthropology. Bioarchaeology and Social Theory. Springer, pp. 39-64. ISBN 9783030273934 doi: https://doi.org/10.1007/978-3-030-27393-4 Available at https://centaur.reading.ac.uk/98376/

It is advisable to refer to the publisher's version if you intend to cite from the work. See Guidance on citing.

Published version at: http://dx.doi.org/10.1007/978-3-030-27393-4

To link to this article DOI: http://dx.doi.org/10.1007/978-3-030-27393-4

Publisher: Springer

All outputs in CentAUR are protected by Intellectual Property Rights law, including copyright law. Copyright and IPR is retained by the creators or other copyright holders. Terms and conditions for use of this material are defined in the End User Agreement. 


\section{CentAUR}

Central Archive at the University of Reading

Reading's research outputs online 


\title{
Like Mother, Like Child: Investigating perinatal and maternal health stress in Post-Medieval London.
}

\author{
Claire M. Hodson and Rebecca L. Gowland \\ Department of Archaeology \\ Durham University \\ South Road \\ Durham, DH1 3LE \\ E-mail: c.m.hodson@durham.ac.uk; rebecca.gowland@durham.ac.uk
}

\begin{abstract}
Post-Medieval London ( $16^{\text {th }}-19^{\text {th }}$ centuries) was a stressful environment in which to be poor. Overcrowded and squalid housing, physically demanding and risky working conditions, air and water pollution, inadequate diet, and exposure to infectious diseases created high levels of morbidity and low life expectancy. All of these factors pressed with particular severity on the lowest members of the social strata, with burgeoning disparities in health between the richest and poorest. Fetal, perinatal and infant skeletal remains provide the most sensitive source of bioarchaeological information regarding past population health and in particular maternal wellbeing. This chapter examined evidence for chronic growth and health disruption in 136 fetal, perinatal and infant skeletons from four low status cemetery samples in post-Medieval London. The aim of this study was to consider the impact of poverty on the maternal/infant nexus, through an analysis of evidence of growth disruption and pathological lesions. The results highlight the dire consequences of poverty in London during this period from the very earliest moments of life.
\end{abstract}

\section{Keywords}

Fetal, infant, growth disruption, pathological lesions, socio-economic status, poverty, DOHaD 


\section{Introduction}

Post-Medieval London $\left(16^{\text {th }}-19^{\text {th }}\right.$ centuries $)$ was a thriving urban centre which witnessed rapid population expansion, particularly during the Industrial Revolution (Beier 1978; DeWitte et al. 2016; Lewis 2002a). Throughout the post-Medieval period London was an important global centre for trade and migration, and the Industrial Revolution heralded a new technological age, which provided unrivalled economic potential (Storey 1992). Despite this progression and a burgeoning middle class, social inequalities between the richest and poorest members of society continued to widen throughout this period, particularly throughout the $19^{\text {th }}$ century (Lewis 2002b; Lindert 1994; Storey 1992).

For the poor, the reality of life in post-Medieval London was that of an overcrowded and unsanitary urban centre, with squalid living and working conditions and inadequate nutrition (DeWitte et al. 2016; Forbes 1972). The capital held a strong attraction for economic migrants (Beier 1978), most typically relocating from pastoral and agricultural occupations. However, the jobs in London were often temporary and/or piecemeal, and the accommodation and food was expensive compared to the rural areas (Beier 1978; DeWitte et al. 2016). Areas of slum housing were notorious hotspots for disease and infection as a result of the insanitary living conditions (Beier 1978). Houses were divided up for rent by opportunistic landlords resulting in numerous people sharing rooms and even the cellars were considered habitable enough to let (Beier 1978; Boulton 2000).

Marked disparities in socioeconomic status (SES) are known causative factors of growth and health disruption in childhood, influencing early life morbidity and mortality (Babones 2008; Bogin and Loucky 1997; Cavigelli and Chaudhry 2012; García et al. 2017; Farmer 1996; Saunders and Hoppa 1993; Schell 1997; Thorsell and Nätt 2016;). As a result, adversity often manifests within the growing body and skeleton, meaning that the archaeological analysis of human remains can provide unique insights into socially-mediated risk factors for disease (e.g. De la Rúa et al. 1995; DeWitte et al. 2016; Ives and Humphrey 2017; Lewis and Gowland 2007; Pinhasi et al. 2006). Typically, higher SES correlates with healthier, larger and taller offspring and thus delayed growth and pathological lesions (as evidence of health disruption) are useful 
proxies to assess the impact of SES (Bogin 2001). This is because social status mediates resource access; the higher the socioeconomic status of the individual, the greater the availability of nutritious food and better living and working conditions, all of which improve physiological and psycho-social well-being (Floud et al. 1990; Halfon et al. 2014; Martorell and Habicht 1986; Mays et al. 2009; Nicholas and Steckel 1991; Robb et al. 2001; Schell 1997; Stinson 2000; Steckel 2009).

Social status continues to be one of the strongest determinants of health today, with those at the very bottom of the social ladder often experiencing vastly poorer health and shorter life expectancies than those at the top (Farmer 1996; Marmot 2005). Today, in low socioeconomic groups, average infant mortality is estimated to be 52 per 1000 live births (World Health Organization 2018). This is over thirteen times the current rate of infant mortality in the UK (3.8 per 1000 live births), and eight times the current rate in the USA (5.8 per 1000 live births); both countries considered representative of high socioeconomic status regions (World Health Organization 2018). It was estimated in 2010 that up to 32.4 million babies were born into the world in an already undernourished condition (Oxford University News 2014). Consequently, despite modern clinical interventions and increased awareness of what is required to secure good health, social disparities in resource access is still one of the biggest factors in determining birth and health outcomes (Cavigelli and Chaudhry 2012; Phelan et al. 2010; Robertson et al. 2013).

The first 1000 days of life have been characterised as a period developmental plasticity and heightened susceptibility to adversity (Barker et al. 2002). The skeletal remains of fetal (<36 gestational weeks of age (GWA)), perinatal (36 - 44 GWA) and infant (44 GWA to 1 year of age) individuals therefore reflect the consequences of social inequalities most severely. The bioarchaeological analysis of non-adult skeletal remains has proliferated over recent decades (Halcrow and Tayles 2008; Humphrey 2000a; Lewis 2002a; 2002b; Mays et al. 2017). Despite this, fetal, perinatal and infant individuals continue to be under-represented in the literature (Halcrow and Tayles 2008; Halcrow et al. 2017; Kamp 2015; Lewis 2018; Sánchez Romero 2017). Given the inter-connectivity of the infant/mother nexus and developmental plasticity in early life, the analysis of these youngest individuals can provide unparalleled insight into pre- 
and postnatal experiences within different socio-cultural and economic milieu (Agarwal 2016; Baxter 2005; Halcrow and Ward 2017; Lewis 2007; Scheuer and Black 2000a).

Several bioarchaeological studies have considered growth and health in London during the postMedieval period (e.g. Beaumont et al. 2013; DeWitte et al. 2016; Ogden et al. 2007; Newman and Gowland 2017; Nitsch et al. 2011). However, despite this abundance of research, few studies have considered the fetal, perinatal and infant individuals in detail. Thus, this chapter presents the first study to consider fetal/infant and maternal health in relation to social inequity during this dynamic period in London's history.

\section{Burial in Post-Medieval London}

In total, 136 fetal/infant individuals were analysed for evidence of growth disruption and pathological lesions from four post-Medieval sites, which included Broadgate, St Bride's Lower, Cross Bones and St Thomas' Hospital, curated by the Museum of London (Table 1.).

Broadgate was a municipal cemetery founded in AD 1569 by the City of London to relieve overcrowding in the adjacent parish cemeteries (Museum of London 2015; Schofield and Maloney 1998). This new churchyard became the burial place predominantly for the poorer classes (Harding 2002). Excavations revealed that the burials were tightly packed, with as many as eight individuals per cubic meter in some areas (Dyson et al. 1987; Schofield and Maloney 1998). Most individuals recovered had not been buried in coffins, again reflecting the lowly social status of the people buried here.

St Bride's Lower was similarly formed in response to congestion and overcrowding of the original churchyard (Upper Ground cemetery) associated with St Bride's to the south (Kausmally 2008; Miles and Conheeney 2005). This alternate cemetery was used throughout the $17^{\text {th }}$ to $19^{\text {th }}$ centuries by those who lived in the parish of St Bride's (Kausmally 2008). The Lower churchyard was the cheapest burial place in the parish and, while not a desirable burial location, was heavily used throughout the $18^{\text {th }}$ and $19^{\text {th }}$ centuries (Miles and Conheeney 2005). In addition, some of those buried in St Bride's Lower cemetery were likely to have been inmates in the adjacent Bridewell Workhouse and Fleet Prison (Kausmally 2008; Miles and Conheeney 
2005). During excavation, individual grave cuts were difficult to identify due to the densely packed nature of the burial ground and the constant inter-cutting of graves to accommodate more burials (Miles and Conheeney 2005).

Cross Bones Cemetery, located in Southwark (Brickley et al. 1999), was a burial place considered to be for the poorest individuals living in London at this time. It is thought to have originally been an unconsecrated burial ground for women working in brothels on Bankside (Brickley et al. 1999; Mikulski 2007). The burial ground came into 'proper' use in 1760, and until its closure in 1853, remained a pauper cemetery (Brickley et al. 1999; Mikulski 2007). Again, due to the densely packed nature of the burials the identification of individual grave-cuts during excavation was challenging.

St Thomas' is a $17^{\text {th }}$ century burial ground associated with St Thomas' Hospital (Jones 1991). Excavation revealed a series of three mass burial trenches dating to the $17^{\text {th }}$ century. The burials excavated from this site are considered to be either those of paupers or victims of an epidemic event (Bekvalac 2007); there is evidence of rapid burial, with little or no soil found between the multiple layers of bodies, suggestive of a catastrophic event (Jones 1991).

\section{Growth Disruption}

The human body is highly labile and physiological plasticity refers to the ability of an individual, group or population to change size and shape in response to environmental stimuli, be that positively or negatively (Bogin and Loucky 1997; Bogin and Rios 2003; Bogin 2001; Goodman and Martin 2002; Clukay et al. 2018). During the early years of growth and development the size and shape of the human skeleton is particularly plastic (Bogin and Rios 2003). The nature of cell development and the constant need to exchange, replace and renew constituents of those cells, and develop new cells, means the body is always influenced by the environment. Therefore, the constant turnover of cells and the dynamic state of the body allows us to continually interact, react and adapt to a changing environment (Tanner 1978).

It has long been considered that there are 'critical periods' of human growth and development, in which particular environmental stimuli have greater impact, channelling growth in accordance to 
these benefits and/or limitations (Cameron and Demerath 2002; Gluckman and Hanson 2005; Hahn 1972; Helfrecht et al. 2017; Kuzawa and Quinn 2009). The first 1000 days of life - from conception through to infancy - have been identified as the most fundamental for developmental plasticity (Barker 2012; Said-Mohamed 2018), making them the most influential in shaping future growth and health (Holdsworth \& Schell 2017). Fetal, perinatal and infant individuals are consequently the most vulnerable to a variety of social and environmental onslaughts (Bogin 2001; Dancause et al. 2012; Kuzawa and Quinn 2009; Kuzawa and Sweet 2009; Lejarraga 2012; Oestreich 2008; Mays et al. 2009; Winick et al. 1972).

To identify growth disruption in bioarchaeology, it is necessary to calculate both dental and skeletal age-at-death estimates to identify variation between the two. Dental development is widely utilised to infer chronological age-at-death of non-adult individuals (AlQahtani et al. 2014; Hillson 2005; Lewis 2007; Moorrees et al. 1963b). Teeth grow systematically from the tip of the crown to the root and this occurs at relatively consistent ages for each tooth (Hillson 2005). Though both genetic and environmental factors may affect tooth growth and development (Heuzé and Cardoso 2008; Massler et al. 1941), it is widely accepted that tooth development shows less chronological variability and fluctuation than skeletal growth and development parameters (Bang 1989; Bolaños et al. 2000; Gustafson \& Koch 1974; Hoppa and Fitzgerald 1999; Humphrey 2000a; Liversidge and Molleson 2004; Moorrees et al. 1963b; Satterlee Blake 2018). Estimation of chronological age using dental development has also been found to be more accurate in younger infants and children (AlQahtani et al. 2014; Bolaños et al. 2000; Lewis 2007). Consequently, within this study, dental age estimates are used as a proxy for chronological age. Tooth cusp development was recorded using Moorrees et al. (1963a; 1963b) and age-at-death estimates attributed using the dental development atlas developed by AlQahtani et al. (2010).

Metric assessment of fetal, perinatal and infant skeletal remains is the most commonly used method for estimating chronological age-at-death in this very young age group (Humphrey 2000b; Lewis 2007; Utczas et al. 2017). Diaphyseal length measurements of the femora, tibiae, and humeri were recorded and gestational age-at-death estimates calculated using the published linear regression equations by Scheuer et al. (1980). However, it has been widely accepted that 
the relationship between diaphyseal length and chronological age is not a reliable one (Lewis 2007). Long bone growth is known to arrest during periods of nutritional deficiency or infectious disease and has therefore been shown to be a sensitive marker of physiological stress (McDade et al. 2008; Pomeroy et al. 2012).

\section{Health Disruption}

Bioarchaeological interpretations of health rely on the identification and interpretation of skeletal lesions, as well as changes consistent with evidence of growth disruption, as mentioned previously (Armelagos and Goodman 1991; Goodman et al. 1988; Goodman and Martin 2002; Reitsema and McIlvaine 2014). Evidence of these skeletal markers are commonly referred to as 'stress indicators' (Goodman et al. 1988; Goodman and Martin 2002; Lewis and Roberts 1997; Reitsema and McIlvaine 2014) and can represent a variety of pathological conditions such as specific and non-specific infections, trauma and metabolic disturbances (Goodman and Martin 2002; Reitsema and McIlvaine 2014).

Stressors are considered to be those factors that have a negative and detrimental impact upon growth and health (Goodman et al. 1988; Goodman and Armelagos 1989; Reitsema and McIlvaine 2014). Thus, stress and stressors are correlated with both metric (growth) and pathological (disease) changes, suggested to be indicative of a physiological response to adversity (Bush 1991). Stressors in this context include factors which influence pre- and postnatal life, such as maternal health/disease status, intra- and extrauterine nutrition, social, cultural and environmental variables, as well as the genetic predisposition and inherited fragility of the child. Consequently, stressors are defined as the multitude of both intrinsic and extrinsic factors that can affect and alter normal growth and health (Bush and Zvelebil 1991; Goodman and Armelagos 1988; Goodman et al. 1988).

For the purposes of this study, stress was assessed by macroscopic assessment of pathological lesions identified on the fetal, perinatal and infant skeletons. Descriptions and photographs of each pathological change/lesion was taken by the first author. In particular, evidence for pathological new bone formation (NBF), lytic lesions, metaphyseal expansion and evidence of 
limb bowing were recorded (See Fig. 1). Table 2. outlines the features recorded for each pathological lesion for the purposes of this analysis.

\section{Mum's the Word: The Mother-Infant Nexus}

Since the 1980s, Barker and colleagues (e.g. Barker and Osmond 1986; Barker 1994) have revealed the significant impact of prenatal exposure to stressors on future growth and health (Halfon et al. 2014; Luo et al. 2006; 2010). These life course models (e.g. Developmental Origins of Health and Disease (DOHaD) hypothesis) suggest that short- and long-term health outcomes are not a product of genetic endowment alone, but are also regulated by environmental, social, cultural and psychological factors experienced in early life (Agarwal 2016; Barker et al. 2002; Halfon et al. 2014; Thorsell and Nätt 2016). A high degree of plasticity during the pre- and postnatal periods (Gowland 2015; Agarwal 2016; Said-Mohamed et al. 2018; Satterlee Blake 2018; Wadhwa et al. 2011) means that offspring growth and health status reflects the varying maternal and environmental exposures encountered. Furthermore, both previous and existing maternal life course experiences can impact upon the growing fetus/perinate/infant (Barker et al. 2012; Gowland 2015; Redfern 2003; Said-Mohamed et al. 2018).

Exposure to a variety of conditions/stressors can result in epigenetic changes, those affecting gene expression, rather than the underlying DNA sequence (Cattaneo 1991; Chmurzynska 2010; Glover 2015; Halfon et al. 2014; Kuzawa 2012; Mortier and Vanden Berghe 2012). Epigenetic changes predispose our susceptibility, and/or resilience to disease, through altering the structure and function of various biological systems (Barker et al. 2012; Cameron and Demerath 2002; Chmurzynska 2010; Luo et al. 2006; Mortier and Vanden Berghe 2012; Slack 1991). Importantly, immune function has been found to alter as a consequence of prenatal stress exposure (Boersma and Tamashiro 2015). Furthermore, some epigenetic traits can become 'embedded', transferred from parent to child, and subsequently to grandchild, suggesting epigenetic signatures may be transmitted over multiple generations (Boersma and Tamashiro 2015; Glover 2015; Gowland 2015; Halfon et al. 2014; Kuzawa and Quinn 2009; Satterlee Blake 2018; Thorsell and Nätt 2016;). Holland-Jones (2005) has termed this a 'downstream effect'. The recognition that prenatal life can be influenced by previous multi-generational experiences challenges our ability to determine when an individual's biography truly begins (Gowland 2015). 
Additionally, offspring experiences rely on maternal ability to supply and buffer nutrients and antibodies via both the placenta and lactation. Therefore, fetal, perinatal and infant life stages are inherently fragile, intricately bound to maternal life course experiences and wellbeing. As such, assessment of fetal, perinatal and infantile growth and health status provides a tangible reflection of maternal, as well as community, health and wellbeing (Baxter 2005; Goodman and Armelagos 1989; Lewis 2007; Redfern 2003).

\section{Maternal-Offspring Stress: The Evidence}

Of the 136 individuals examined, all were assessed for evidence of pathological lesions. A total of 82 of these individuals had teeth available for age estimation. Diaphyseal lengths from the humerus, femur and tibia, were available in 93, 86 and 84 individuals respectively (Fig. 2). To assess evidence for growth disruption, skeletal age estimates for femoral, humeral and tibial measurements were compared to dental age, where possible (Table 3.). In total, 67 individuals had both dental and skeletal elements available for assessment. Average skeletal age estimates were consistently younger than dental age, with those in the infant age categories (> $46 \mathrm{GWA}$ ) demonstrating a difference of as much as 13 to 22 gestational weeks younger (Table 3.) In total 51 individuals had femora, 60 humeri, and 48 tibiae measurements in addition to the dentition. Seventeen individuals had dental and skeletal age estimates for which even the widest extents of the error ranges do not overlap (Fig. 3), strongly indicative of growth disruption. Of these 17 individuals, 10 were from the archaeological sample of Cross Bones, 5 were from St Brides' Lower, and 1 individual was identified from the sites of Broadgate and St Thomas' Hospital (Table 4.1). Though this is likely a product of sample size and differential preservation, around $20 \%$ of individuals showed evidence of growth disruption in three of the sites (Table 4.1). Consideration of individual growth disruption by dental age estimate (Table 4.2) shows that those aged 58 GWA and 64 GWA had the highest prevalence of growth disruption.

Examination of the cranial vault elements of 136 individuals has revealed that the frontal and parietal bones more commonly exhibit pathological lesions (of all types) than the occipital bone, whilst the tibia is the most affected of the long bones (Table 5.1). For all the cranial elements new bone formation $(\mathrm{NBF})$ is the most common pathological lesion identified, although the 
temporal bone shows the highest prevalence rate of lytic lesions (Table 5.2). NBF is also the most typical pathological lesion identified on the long bones, although metaphyseal expansion is also prevalent (Table 5.2). The NBF on the frontal bone and parietal bone was typically lamellar, whereas NBF on the other cranial bones was more commonly woven in nature (Table 5.3). Woven bone was also more frequently identified on the long bones than lamellar bone (Table 5.3). Comparison of the location of both the NBF and lytic lesions shows that cranial elements were most commonly affected endocranially, whilst long bone elements were most frequently affected circumferentially or anteriorly (Table 5.4).

Individuals from Cross Bones had the highest prevalence of lesions on their postcranial bones, with a very high number of individuals also having lesions on their cranial bones (Table 5.5). The results from the St Thomas' Hospital sample is not representative in terms of pathology because of the very small sample size. When considered in terms of dental age (Table 5.6) both fetal and infant individuals exhibited pathological lesions. Pathological lesions were consistently present in all age categories for the cranial vault elements and similar prevalence rates were observed for the long bones. Pathological lesions on the tibiae show a relatively consistent prevalence rate for individuals aged between 38 and 58 GWA, with only those aged 64 GWA having a higher prevalence rate of lesions.

\section{Discussion}

Fetal, perinatal and infant individuals are widely considered to be the most vulnerable to adverse environmental conditions and experiences (Humphrey 2000a; Newman and Gowland 2017). With both an under-developed immune system (Halcrow and Tayles 2008; Perry 2006; Rogers 1997), and a total reliance on others for care and well-being both pre- and postnatally (Lewis 2017a), these young individuals are the most physiologically susceptible members of a community to health and growth disruption. Assessment of 136 individuals from four low status post-Medieval sites has provided evidence for the detrimental effects of such adverse environments for growth and health. Individuals from all four of the archaeological samples show evidence for delayed growth and disease, likely a result of the impoverished and squalid conditions to which their mothers were exposed as members of the poorer class in London at this time. 
Delayed growth was observed in all age categories (Table 4.1), though post-natal infants $(52,58$ and 64 GWA) show the largest differences between dental and skeletal age estimates on average (Table 3). Increased evidence for growth disruption in the older age categories (52-64 GWA) may be indicative of a postnatal drop-off in growth. The ability for a mother, regardless of her own health status, to buffer the child from environmental and external factors is greater in utero than postnatally (Gowland 2015) - though passive immunity and nutritional buffering can be provided by breastfeeding (See Miller, this volume; Eisenberg et al. 2017; Lewis 2017b). Therefore, greater growth disruption in the infant age group may indicate that their postnatal buffering was insufficient to protect them from the extensive pathogenic environment into which they were born.

Individuals within the 64 GWA dental age category also show a diverging growth trajectory between femoral, humeral and tibial elements, with larger differences between dental and tibial and humeral age estimates, than between the dentition and femur. Normal growth should result in all skeletal elements following a similar trajectory. Variation in growth, whereby one element appears to be disrupted or limited to a greater extent than other skeletal elements, is often considered to be a reflection of poor environment. In particular, the tibia is regarded as more susceptible to growth disruption (Pomeroy et al. 2012). The results of this study likewise indicate that the tibia, as well as the humerus, reflect the greatest growth disruption. Furthermore, this analysis shows that the tibia is the long bone which shows the highest prevalence rates of pathology (Table 5.1), corroborating the assumption that this bone is the most sensitive to growth disruption and health stress.

Individuals showing prenatal growth disruption represent the most severely deprived, where maternal regulation of the intrauterine environment was highly compromised. Growth disparities within infants and older children have been widely documented, particularly in regards to varying socioeconomic status and poverty factors (Sinclair 1985). Results of this study suggest that socioeconomic and environmental impacts on growth can be traced in individuals of much younger ages, and even within pre- and perinatal individuals. This study has shown that individuals aged dentally to be as young as 38 GWA show evidence of growth disruption. 
Growth delay is a cumulative process, whereby evidence for disruption increases as the individual continues to be exposed to the stressor. For significant growth changes to occur in individuals as young as $38 \mathrm{GWA}$, chronic exposure to poor health and nutrition throughout the prenatal period is likely.

Individuals of all ages had pathological skeletal changes, indicative of both a precarious pre- and postnatal environment. This provides evidence for very poor maternal health, to the extent that mothers were unable to adequately buffer their developing infant from adversity. The identification of high prevalence rates of pathological lesions in postnatal infants (Table 5.6) suggests that maternal health and/or the ability to care for the offspring continued to be severely compromised into the postpartum environment, ultimately leading to the death of the infant.

One note of caution that is frequently highlighted in relation to the diagnosis of pathological lesions in fetal/infant remains is the differentiation between abnormal bone changes and normal growth (Lewis 2017a: 3). In this study there is a clear link between growth disruption and pathological lesions suggesting that the NBF observed was not related to normal growth. Furthermore, a number of the pathological changes were very dissimilar to the type of woven bone produced during the normal growth processes (i.e. very thickened layers of lamellar and woven bone, metaphyseal expansion and porosity). Finally, if the new bone formation identified on the postcranial elements was solely a consequence of normal bone growth one would expect to see it on at least some elements of all individuals during this period of rapid growth, but this was not the case.

Cranial lesions were found to be present in all individuals, regardless of age. This may suggest that these lesions are 'normal', although it is important to remember that this sample represents deceased infants. Evidence here suggests that a substantial proportion of these were likely to have been chronically ill due to the correlation between cranial and post-cranial skeletal lesions, in addition to growth deficits. It is well known that in times of stress, the body prioritises growth of particular skeletal and soft-tissue structures, with the brain sitting at the top of this physiological hierarchy (Agarwal 2016; Barker et al. 2012; Said-Mohamed et al. 2018); Infants dedicate up to $87 \%$ of their resting metabolic rate to brain development (Bogin 2001, 2012; Said- 
Mohamed et al. 2018). This prioritisation requires the cranial bones to be equally adequately developed (Karsenty and Kronenberg 2003). Therefore, the speed of growth within bones of the cranium is considered to be a reflection of the rapidity of brain growth during this age (Lewis 2007; Scheuer and Black 2000b). When growth disruption is experienced, there is often a tradeoff between skeletal structures (Barker et al. 2012; Said-Mohamed et al. 2018). Typically, longitudinal growth of the long bones is arrested in favour of continued development of the brain and bones of the cranium (Aiello and Wells 2002; Kuzawa et al. 2014; Said-Mohamed et al. 2018; Sandman et al. 2016). Within this sample there is evidence of longitudinal growth disruption in the postcranial limb bones, alongside a high prevalence of lesions within the cranium. Almost all of the cranial lesions are NBF, which is lamellar in nature, indicative of a healing response. Therefore, increased evidence of pathological changes within the cranium may suggest the body trying to maintain growth in these elements despite adversity as evidenced in the postcranial bones.

Diseases of poverty are typically those associated with nutritional deficiency as a result of reduced food intake and a limited diversity of available foodstuffs (Dowler and Dobson 1997). NBF and metaphyseal expansion, where the metaphyses splay (see Fig. 1), on the long bones are pathological changes consistent with metabolic deficiencies. Vitamin C and vitamin D deficiencies are the most commonly considered metabolic diseases within the bioarchaeological literature because evidence of their skeletal markers can be commonly recognised. However, the synergistic effects of nutritional insufficiencies alongside infectious disease means that pinpointing a specific cause on the basis of skeletal lesions can be problematic. Nevertheless, vitamin D deficiency can be inferred due to bowing identified within some of the limb bones assessed $(N=12)$. Although these individuals were too young for their limbs to have been weightbearing, intrauterine restriction can be responsible for these changes (Abbott 1901) and have been identified clinically in cases of congenital rickets (Anatoliotaki et al. 2003; Innes et al. 2002). Consequently, evidence for expansion at the metaphyses, combined with extensive expansion of the trabecular bone structure, suggests that many of the individuals, and subsequently their mothers, were chronically vitamin D deficient. Similarly, scurvy has been identified clinically within fetal and perinatal individuals (Besbes et al. 2010) and is considered to occur when maternal intake of fresh fruit and vegetables is low (Brickley and Ives 2006). 
Skeletal changes consistent with vitamin $\mathrm{C}$ deficiency also includes expansion of the metaphyses and periosteal NBF as a consequence of weakened blood vessels which easily rupture and haemorrhage (Aufderheide \& Rodríguez-Martín 1998; Brickley and Ives 2006; Besbes et al. 2010). As such, pathological lesions identified within the samples assessed may also be consistent with Vitamin $\mathrm{C}$ deficiency. Vitamin $\mathrm{C}$ deficiency has traditionally been suggested to only be observable in the skeleton after $\sim 6$ months of chronic deficiency, although this has been recently disputed (Snoddy et al. 2018) and it is likely that it will manifest more quickly during the rapid growth and energetic demands of the intrauterine period (Brickley and Ives 2006; Mays 2014). Skeletal evidence for Vitamin C deficiency within the sample suggests severe prenatal deficiency as a consequence of maternal insufficiency.

Urban environments during the post-Medieval period were hotbeds for a range of infectious diseases such as cholera, smallpox, measles, whooping cough, tuberculosis, scarlet fever and typhoid (Lewis 2002b; Forbes 1972). The overcrowding and lack of sanitary housing for those in London's slums exposed them to a higher risk of infection. Poverty is the most predominant factor regulating health, growth and mortality (Feinstein 1993). There is an intrinsic link between immune function and social position, with exposure to stressful early life environments altering immunity and regulation of bodily responses to infections (Babones 2008). This means that maternal stress will predispose individuals to inadequate immune responses and therefore susceptibility to disease. The fetal, perinatal and infant remains from Cross Bones, a burial ground for the very poorest individuals, shows the greatest evidence for health and growth disruption, indicative of an inability to regulate and overcome stressors. Southwark, in which Cross Bones is situated, was described as '...nurseries...of the begging poor that swarm within the City' (Beier 1978). A recent study by Newman and Gowland (2017) examining the skeletal remains of older infants and children also highlight Cross Bones as the sample showing greatest growth and health disruption as a consequence of increased morbidity and mortality risks.

In addition to poor living conditions, pregnancy-related cultural practices, and treatment and care of the child once born will impact upon growth and health status (Finlay 2013; Satterlee Blake 2018; e.g. Wilkie 2013). Many low social status women in the $19^{\text {th }}$ century had to return to work as soon as possible after birth, as household economies often relied on both parents earning an 
income (Boulton 2000). In such circumstances, the infant may not have been breastfed, and instead left in the care of elderly parents, neighbours or siblings (Boulton 2000). Breastfeeding practices are strongly regulated by social status (DeWitte et al. 2016; Fildes 1988, 1995; Nitsch et al. 2011). Perinates and infants who are artificially fed have been found to have increased disease and mortality risks (DeWitte et al. 2016; Fildes 1995). Though wet-nursing was popular among the higher social strata during the period in question, dry-feeding (mixture of grains, water, broth and milk) became popular throughout society (DeWitte et al. 2016). Breastmilk is important for both the nutritional and immunological wellbeing of the infant (See Miller see volume; Lewis 2017b; Eisenberg et al. 2017). Breastmilk enables the transfer of maternal antibodies, as well as triggering the infant's own immune system and functioning (DeWitte et al. 2016). Maternal breast milk is also known to have high concentrations of vitamin A, needed to sustain rapid growth in the postpartum environment (Fujita et al. 2017). Therefore, restriction and withholding of this dietary resource predisposes the infant to increased disease susceptibility. Growth and health disruption identified in postnatal infants may reflect the lack of breastfeeding, or the mother being simply unable to feed the child as a result of her own failing health or death in childbirth.

No individuals, from any of the samples, were dentally aged to be fetal (<36 GWA); however, dental remains are less likely to be retrieved at excavation in such young infants. By contrast, a total of 35 individuals had femoral age estimates which fall into the fetal age range, with 36 individuals having tibial, and 39 individuals having humeral diaphyseal length measurements which generate fetal age-at-death estimates. The youngest age estimates for the femora, tibiae and humeri were 26, 25 and 26 GWA respectively (Fig. 2), suggesting that stillborn or miscarried infants were not unilaterally excluded from burial within the cemeteries.

Increasing research into epigenetics and phenotypic plasticity has established a link between early life stress and intergenerational consequences (Gowland 2015; Mays et al. 2017; e.g. Bateson et al. 2004). Ultimately, adverse early life experiences decrease longevity and increase frailty (Gowland 2015). Adaptive phenotypic consequences become integral to future generations' genetic structure, meaning what was an adaptive response by one individual becomes the basis of 'future life history tactics' in the offspring (Holland Jones 2005). This 
potentially predisposes offspring to (mal)adaptation in response to the adverse or beneficial environments experienced. Thus, the health and growth disruption identified within these infants may represent multigenerational, cumulative consequences of deprived living environments. Maternal health status was severely compromised, but this may well have been an accumulation of poor health that began with her own mother and grandmother and does not simply reflect the nine-month gestational window (Richardson et al. 2014).

\section{Conclusion}

The urban squalor and poor nutrition that characterised the lives of the poor in post-medieval London is known to have had a detrimental effect on health and life expectancy. This study is the first to examine the effect of this environment on the infant/mother nexus and the devastating consequences of extreme poverty on the growth and health of infants. Evidence of, in some instances very severe growth disruption, along with high prevalence rates of pathological lesions, highlights the woeful state of maternal, and by extension, female health during this period. This research has resonance for developing and post-industrial cities of today, in which stark differences in infant mortality between the richest and the poorest still exist. It highlights the importance of investing in, not only maternal health, but the health of all women, whatever their social status, in order to reduce infant mortality and the life-long chronic and infectious disease burdens.

\section{Acknowledgements}

The authors wish to thank Dr Rebecca Redfern and Jelena Bekvalac at the Centre for Human Bioarchaeology, Museum of London for their support in enabling access to the skeletal collections. The authors also wish to express their gratitude to the Wenner-Gren Foundation for providing funding for the colloquium from which this book transpired. Dr Claire Hodson would also like to thank the AHRC for her doctoral funding, during which, data presented here was collected (Grant Number: AH/K502996/1). 


\section{$\underline{\text { References }}$}

Abbott, F. C. (1901). Intrauterine Rickets. The British Medical Journal, 2(2123), 597-599.

Agarwal, S. (2016). Bone Morphologies and Histories: Life Course Approaches in Bioarchaeology. Yearbook of Physical Anthropology, 159(S61), 130-149.

Aiello, L. C. \& Wells, J. C. K. (2002). Energetics and the evolution of the genus Homo. Annual Review of Anthropology, 31(1), 323-338.

AlQahtani, S. J. Hector, M. P., \& Liversidge, H. M. (2014). Accuracy of Dental Age Estimation Charts: Schour and Massler, Ubelaker, and the London Atlas. American Journal of Physical Anthropology, 154(1), 70-78.

AlQahtani, S. J. Hector, M. P. \& Liversidge, H. M. (2010). The London Atlas of Human Tooth Development and Eruption. American Journal of Physical Anthropology, 142(3), 481-490.

Anatoliotaki, M., Tsilimigaki, A., Tsekoura, T., Schinaki, A., Stefanaki, S. \& Nikolaidou, P. (2003). Congenital rickets due to maternal vitamin D deficiency in a sunny island of Greece. Acta Paediatrica, 92(3), 389-391.

Armelagos, G. J. \& Goodman, A. H. (1991). The concept of stress and its relevance to studies of adaptation in prehistoric populations. Collegium Antropologicum, 15, 45-58.

Aufderheide, A. \& Rodríguez-Martín, C. (1998). The Cambridge Encyclopedia of Human Paleopathology. Cambridge: Cambridge University Press.

Babones, S. J. (2008). Income inequality and population health: Correlation and causality. Social Science and Medicine, 66(7), 1614-1626.

Bang, G. (1989). Age changes in teeth; developmental and regressive. Age Markers in the Human Skeleton, 1, 211-235.

Barker, D. J. P. (1994). Mothers, Babies, and Disease in Later Life. London: BMJ Publishing Group.

Barker, D. J. P. (2012). Developmental origins of chronic disease. Public Health, 126(3), 185189. 
Barker, D. J. P., Eriksson, J. G., Forsén, T., \& Osmond, C. (2002). Fetal origins of adult disease: strength of effects and biological basis. International Journal of Epidemiology, 31(6), 12351239 .

Barker, D. J. P., Lampl, M., Roseboom, T. \& Winder, N. (2012). Resource allocation in utero and health in later life. Placenta, 33(S2), 30-34.

Barker, D. \& Osmond, C. (1986). Infant mortality, childhood nutrition, and ischaemic heart disease in England and Wales. Lancet, 8489(1), 1077-1081.

Bateson, P., Barker, D., Clutton-Brock, T., Deb, D., D’Udine, B., Foley, R. A., Gluckman, P., Godfrey, K., Kirkwood, T., Mirazón Lahr, M., McNamara, J., Metcalfe, N. B., Monaghan, P., Spencer, H. G., \& Sultan, S. E. (2004). Developmental plasticity and human health. Nature, 430(6998), 419-421.

Baxter, J. E. (2005). The Archaeology of Childhood: Children, Gender, and Material Culture. California: AltaMira Press.

Beaumont, J., Geber, J., Power, N., Wilson, A., Lee-Thorpe, J., \& Montgomery, J. (2013). Victims and Survivors: Stable Isotopes Used to Identify Migrants from the Great Irish Famine to $19^{\text {th }}$ Century London. American Journal of Physical Anthropology, 150(1), 87-98.

Bekvalac, J. (2007). St Thomas' Hospital cemetery summary. https://www.museumoflondon.org.uk/collections/other-collection-databases-and-libraries/centrehuman-bioarchaeology/osteological-database/post-medieval-cemeteries/st-thomas-hospital-postmedieval. Accessed: November 2016.

Beier, A. L. (1978). Social Problems in Elizabethan London. The Journal of Interdisciplinary History, 9(2), 203-221.

Besbes, L. G., Hadded, S., Meriem, C. B., Golli, M., Najjar, M. F., \& Guediche, M. N. (2010). Infantile Scurvy: Two Case Reports. International Journal of Pediatrics, 2010(Article ID 717518), 1-4.

Boersma, G. J. \& Tamashiro, K. L. (2015). Individual differences in the effects of prenatal stress exposure in rodents. Neurobiology of Stress, 1, 100-108.

Bogin, B. (2001). The Growth of Humanity. New York: Wiley-Liss. 
Bogin, B. (2012). The Evolution of Human Growth. In N. Cameron and B. Bogin (Eds.), Human Growth and Development (pp. 287-324). London: Elsevier.

Bogin, B. \& Loucky, J. (1997). Plasticity, Political Economy, and Physical Growth Status of Guatemala Children Living in the United States. American Journal of Physical Anthropology, 102(1), 17-32.

Bogin, B. \& Rios, L. (2003). Rapid morphological change in living humans; implications for modern human origins. Comparative Biochemistry and Physiology, 136(1), 71-84.

Bolaños, M. V., Manrique, M. C., Bolaños, M. J., \& Briones, M. T. (2000). Approaches to chronological age assessment based on dental calcification. Forensic Science International, 110(2), 97-106.

Boulton, J. (2000). 'It Is Extreme Necessity That Makes Me Do This': Some 'Survival Strategies' of Pauper Households in London's West End During the Early Eighteenth Century. International Review of Social History, 45(S8), 47-69.

Brickley, M. \& Ives, R. (2006). Skeletal Manifestations of Infantile Scurvy. American Journal of Physical Anthropology, 129(2), 163-172.

Brickley, M., Miles, A., \& Stainer, H. (1999). The Cross Bones Burial Ground, Redcross Way, Southwark, London: Archaeological Excavations (1991-1998) for the London Underground Limited Jubilee Line Extension Project (MOLAS Monograph 3). London: Museum of London Archaeology Service.

Bush, H. (1991). Concepts of Health and Stress. In H. Bush and M. Zvelebil (Eds.) BAR International Series 567: Health in Past Societies: Biocultural interpretations of human skeletal remains in archaeological contexts (pp. 11-21). Oxford: BAR Publishing.

Bush, H. \& Zvelebil, M. (1991). Pathology and health in past societies: an introduction. In H. Bush and M. Zvelebil (Eds.) BAR International Series 567: Health in Past Societies: Biocultural interpretations of human skeletal remains in archaeological contexts (pp. 3-9). Oxford: BAR Publishing.

Cameron, N. \& Demerath, E. W. (2002). Critical Periods in Human Growth and Their Relationship to Diseases of Aging. Yearbook of Physical Anthropology, 45(S35), 159-184.

Cattaneo, C. (1991). Direct genetic and immunological information in the reconstruction of health and biocultural conditions of past populations: a new prospect for archaeology. In H. Bush 
and M. Zvelebil (Eds.) BAR International Series 567: Health in Past Societies: Biocultural interpretations of human skeletal remains in archaeological contexts (pp. 39-52). Oxford: BAR Publishing.

Cavigelli, S. A. \& Chaudhry, H. S. (2012). Social status, glucocorticoids, immune function, and health: can animal studies help us understand human socioeconomic-status-related health disparities? Hormones and Behavior, 62(3), 295-313.

Chmurzynska, A. (2010). Fetal programming: link between early nutrition, DNA methylation, and complex diseases. Nutrition Reviews, 68(2), 87-98.

Clukay, C. J., Hughes, D. A., Rodney, N. C., Kertes, D. A., \& Mulligan, C. J. (2018), DNA methylation complex genes in relation to stress and genome-wide methylation in mothernewborn dyads. American Journal of Physical Anthropology, 165(1), 173-182.

Dancause, K. N., Cao, X. J., Veru, F., Xu, S., Long, H., Yu, C., Laplante, D. P., Walker, C. D., \& King, S. (2012). Brief Communication: Prenatal and Early Postnatal Stress Exposure Influences Long Bone Length in Adult Rat Offspring. American Journal of Physical Anthropology, 149(2), 307-311.

De la Rúa, C., Izagirre, N., \& Manzano, C. (1995). Environmental stress in a medieval population of the Basque country. HOMO, 45, 268-289.

DeWitte, S. N., Hughes-Morey, G, Bekvalac, J., \& Karsten, J. (2016). Wealth, health and frailty in industrial-era London. Annals of Human Biology, 43(3), 241-254.

Dowler, E. A. \& Dobson, B. M. (1997). Nutrition and poverty in Europe: an overview. Proceedings of the Nutrition Society, 56(1A), 51-62.

Dyson, L. Malt, D. Wellman, T., \& White, B. (1987). Excavations at Broad Street Station: The Broadgate Development Archive Report. City of London (Unpublished).

Eisenberg, D. T. A., Borja, J. B., Hayes, M. G., \& Kuzawa, C. W. (2017). Early life infection, but not breastfeeding, predicts adult blood telomere lengths in the Philippines. American Journal of Human Biology, 29(4), 1-11.

Farmer, P. (1996). Social inequalities and emerging infectious diseases. Emerging infectious Diseases, 2(4), 259-269. 
Feinstein, J. S. (1993). The Relationship between Socioeconomic Status and Health: A Review of the Literature. The Milbank Quarterly, 71(2): 279-322.

Fildes, V. (1988). Wet nursing. New York: Basil Blackwell Ltd.

Fildes, V. (1995). The culture and biology of breastfeeding: an historical review of Western Europe. In P. Stuart-Macadam and K. Dettwyker (Eds.) Breastfeeding: biocultural perspectives (pp.101-126). Hawthorne: Aldine De Gruyter.

Finlay, N. (2013). Archaeologies of the beginnings of life. World Archaeology, 45(2), 207-214.

Floud, R., Wachter, K.W., \& Gregory, A. (1990). Height, health and history: nutritional status in the United Kingdom, 1750-1980. Cambridge: Cambridge University Press.

Forbes, T. R. (1972). Mortality Books for 1820 to 1849 from the Parish of St. Bride, Fleet Street, London. Journal of the History of Medicine, 27(1), 15-29.

Fujita, M., Lo, Y. J., \& Brindle, E. (2017). Nutritional, inflammatory, and ecological correlates of maternal retinol allocation to breast milk in agro-pastoral Ariaal communities of northern Kenya. American Journal of Human Biology, 29(4): 1-14.

García, A. R., Gurven, M., \& Blackwell, A. D. (2017). A matter of perception: Perceived socioeconomic status and cortisol on the island of Utila, Honduras. American Journal of Human Biology, 29(5), 1-16.

Glover, V. (2015). Prenatal Stress and Its Effects on the Fetus and the Child: Possible underlying Biological Mechanisms. In M. C. Antonelli (Ed.) Perinatal Programming of Neurodevelopment (Volume 10, pp. 269-283). New York: Springer.

Gluckman, P. D. \& Hanson, M. A. (2005). The Fetal Matrix: Evolution, Development and Disease. Cambridge: Cambridge University Press.

Goodman, A. H. \& Armelagos, G. J. (1988). Childhood Stress and Decreased Longevity in a Prehistoric Population. American Anthropologist, 90(4), 936-944.

Goodman, A. H. \& Armelagos, G. J. (1989). Infant and Childhood Morbidity and Mortality Risks in Archaeological Populations. World Archaeology, 21(2), 225-243. 
Goodman, A.H. \& Martin, D. L. (2002). Reconstructing health profiles from skeletal remains. In R. H. Steckel and J.C. Rose (Eds.) The Backbone of History: Health and Nutrition in the Western Hemisphere (pp. 11-60). Cambridge: Cambridge University Press.

Goodman, A. H., Thomas, R. B., Swedlund, A. C., \& Armelagos, G. J. (1988). Biocultural Perspectives on Stress in Prehistoric, Historical, and Contemporary Population Research. Yearbook of Physical Anthropology, 31(S9), 169-202.

Gowland, R. L. (2015). Entangled Lives: Implications of the Developmental Origins of Health and Disease Hypothesis for Bioarchaeology and the Life Course. American Journal of Physical Anthropology, 158(4), 530-540.

Gustafson, G. \& Koch, G. (1974). Age estimation up to 16 years of age based on dental development. Odontologisk Revy, 25(3), 297-306.

Hahn, P. (1972). Lipid Metabolism and Nutrition in the Prenatal and Postnatal Periods. In M. Winick (Ed.) Nutrition and Development (pp. 99-134). London: John Wiley \& Sons Inc.

Halcrow, S. E. \& Tayles, N. (2008). The Bioarchaeological Investigation of Childhood and Social Age: Problems and Prospects. Journal of Archaeological Method and Theory, 15(2), 190215.

Halcrow, S. E., Tayles, N., \& Elliot, G. E. (2017). The Bioarchaeology of Fetuses. In S. Han, T. K. Betsinger, and A. B. Scott (Eds.) The Anthropology of the Fetus (pp. 83-111). New York: Berghahn Books.

Halcrow, S. E. \& Ward, S. M. 2017; Bioarchaeology of Childhood. In H. Montgomery (Ed.) Oxford Bibliographies in Childhood Studies. New York: Oxford University Press.

Halfon, N., Larson, K., Lu, M., Tullis, E. \& Russ, S. (2014). Lifecourse Health Development: Past, Present and Future. Maternal and Child Health Journal, 18(2), 344-365.

Harding, V. (2002). The dead and the living in Paris and London: 1500-1670. Cambridge: Cambridge University Press.

Helfrecht, C., Hagen, E. H., DeAvila, D., Bernstein, R. M., Dira, S. J., \& Meehan, C. L. (2017). DHEAS patterning across childhood in three sub-Saharan populations: Associations with age, sex, ethnicity, and cortisol. American Journal of Human Biology, 30(2), 1-17. 
Heuzé, Y. \& Cardoso, H. F. V. (2008). Testing the Quality of Nonadult Bayesian Dental Age Assessment Methods to Juvenile Skeletal Remains: The Lisbon Collection Children and Secular Trend Effects. American Journal of Physical Anthropology, 135(3), 275-283.

Hillson, S. W. (2005). Teeth. Cambridge: Cambridge University Press.

Holdsworth, E. A. \& Schell, L. M. (2017). Maternal-infant interaction as an influence on infant adiposity. American Journal of Human Biology, 29(5), 1-18.

Holland Jones, J. (2005). Fetal Programming: Adaptive Life-History Tactics or Making the Best of a Bad Start? Journal of Human Biology, 17(1), 22-33.

Hoppa, R. D. \& Fitzgerald, C. M. (1999). From head to toe: integrating studies from bones and teeth in biological anthropology. In. D. Hoppa and C. M. Fitzgerald (Eds.) Human growth in the past: studies from bones and teeth (pp.1-32). Cambridge: Cambridge University Press.

Humphrey, L. (2000a). Interpretations of the growth of past populations. In J. S. Derevenski (Ed.) Children and Material Culture (pp.193-205). London: Routledge

Humphrey, L. (2000b). Growth Studies of Past Population: An Overview and an Example. In M. Cox and S. Mays (Eds.) Human Osteology in Archaeology and Forensic Science (pp. 23-38). London: Greenwich Medical Media Ltd.

Innes, A. M., Seshia, M. M., Prasad, C., Al Saif, S., Friesen, F. R., Chudley, A. E., Reed, M., Dilling, L. A., Haworth, J. C., \& Greenberg, C. R. (2002). Congenital rickets caused by maternal vitamin D deficiency. Paediatric Child Health, 7(7), 455-458.

Ives, R. \& Humphrey, L. (2017). Patterns of long bone growth in a mid-19 ${ }^{\text {th }}$ century documented sample of the urban poor from Bethnal Green, London, UK. American Journal of Physical Anthropology, 163(1), 173-186.

Jones, H. (1991). Preliminary Report of Archaeological Excavations at New London Bridge House, London Bridge Street, S.E.1. Museum of London, Department of Great London Archaeology: London. (Unpublished).

Kamp, K. A. (2015). Children and their Childhoods: Retrospectives and Prospectives. Childhood in the Past, 8(2), 161-169. 
Karsenty, G. \& Kronenberg, H. M. (2003). Postnatal Bone Growth: Growth Plate Biology, Modelling, and Remodeling. In F. H. Glorieux, J. M. Pettifor and H. Jüppner (Eds.) Pediatric Bone: Biology and Diseases (119-133). London: Academic Press.

Kausmally, T. (2008). St Bride's Lower churchyard cemetery summary. https://www.museumoflondon.org.uk/collections/other-collection-databases-and-libraries/centrehuman-bioarchaeology/osteological-database/post-medieval-cemeteries/st-brides-lower-postmedieval. Accessed November 2016.

Kuzawa, C. W. (2012). Early environments, developmental plasticity, and chronic degenerative disease. In N. Cameron and B. Bogin (Eds.) Human Growth and Development (pp. 325-341). London: Elsevier: 325-341.

Kuzawa, C. W., Chugani, H. T., Grossman, L. L., Lipovich, L., Muzik, O., Hof, P. R., Wildman, D. E., Sherwood, C. C., Leonard, W. R., \& Lange, N. (2014). Metabolic costs and evolutionary implications of human brain development. Proceedings of the National Academy of Sciences, 111(36), 13010-13015.

Kuzawa, C. W. \& Quinn, E. A. (2009). Developmental Origins of Adult Function and Health: Evolutionary Hypotheses. Annual Review of Anthropology, 38, 131-147.

Kuzawa, C. W. \& Sweet, E. (2009). Epigenetics and the embodiment of race: developmental origins of US racial disparities in cardiovascular health. American Journal of Human Biology, 21(1), 2-15.

Lejarraga, H. (2012). Growth in Infancy and Childhood: A Pediatric Approach. In N. Cameron and B. Bogin (Eds.) Human Growth and Development (23-56). London: Elsevier.

Lewis, M. E. (2002a). The impact of industrialisation: comparative study of child health in four sites from medieval and post-medieval England (AD 850-1859). American Journal of Physical Anthropology, 119(3), 211-223.

Lewis, M. E. (2002b). Urbanisation and Child Health in Medieval and Post-Medieval England. British Archaeological Reports British Series 229. Oxford: Archaeopress.

Lewis, M. E. (2007). The Bioarchaeology of Children: Perspectives from Biological and Forensic Anthropology. Cambridge: Cambridge University Press.

Lewis, M. E. (2017a). Paleopathology of Children: Identification of Pathological Conditions in the Human Skeletal Remains of Non-Adults. London: Academic Press. 
Lewis, M. E. (2017b) Childcare in the Past: The Contribution of Palaeopathology. In L. Powell, W. Southwell-Wright, and R. Gowland (Eds.) Care in the Past: Archaeological and Interdisciplinary Perspectives. Oxford: Oxbow Books: 23-37.

Lewis, M. E. (2018). Fetal Paleopathology: An Impossible Discipline? In S. Han, T. K. Betsinger, and A. B. Scott (Eds.) The Anthropology of the Fetus (pp. 112-131). New York: Berghahn Books.

Lewis, M. E. \& Gowland, R. L. (2007). Brief and Precarious Lives: Infant Mortality in Contrasting Sites from Medieval and Post-Medieval England (AD 850-1859). American Journal of Physical Anthropology, 134(1), 117-129.

Lewis, M. E. \& Roberts, C. (1997). Growing Pains: The Interpretation of Stress Indicators. International Journal of Osteoarchaeology, 7(6), 581-586.

Lindert, P. (1994). Unequal living standards. In R. Floud and D. McCloskey (Eds.) The economic history of Britain since 1700 (357-386). Cambridge: Cambridge University Press.

Liversidge, H. M. \& Molleson, T. (2004). Variation in Crown and Root Formation and Eruption of Human Deciduous Teeth. American Journal of Physical Anthropology, 123(2), 172-180.

Luo, Z. C., Fraser, W. D., Julien, P., Deal, C. L., Audibert, F., Smith, G. N., Xiong, X., \& Walker, M. (2006). Tracing the origins of 'fetal origins' of adult diseases: Programming by oxidative stress? Medical Hypotheses, 66(1), 38-44.

Marmot, M. (2005). Social determinants of health inequalities. Lancet, 365(9564), 1099-1104.

Martorell, R. \& Habicht. J. P. (1986). Growth in early childhood in developing countries. In F. Falkner and J. Tanner (Eds.) Human Growth: methodology ecological, genetic, and nutritional effects on growth (pp. 241-262). New York: Plenum Press.

Massler, M., Schour, I. \& Poncher, H. G. (1941). Developmental Pattern of the Child as Reflected in the Calcification Pattern of the Teeth. American Journal of Diseases of Children, 62(1), 33-67.

Mays, S. (2014). The palaeopathology of scurvy in Europe. International Journal of Paleopathology, 5, 55-62. 
Mays, S., Ives, R., \& Brickley, M. (2009). The Effects of Socioeconomic Status on Endochondral and Appositional Bone Growth, and Acquisition of Cortical Bone in Children from $19^{\text {th }}$ Century Birmingham, England. American Journal of Physical Anthropology, 140(3), 410-416.

Mays, S., Gowland, R., Halcrow, S., \& Murphy, E. (2017). Child Bioarchaeology: Perspectives on the Past 10 Years. Childhood in the Past, 10(1), 38-56.

McDade, T.W., Reyes-García, V., Tanner, S., Huanca, T., \& Leonard, W.R. (2008).

Maintenance versus growth: investigating the costs of immune activation among children in lowland Bolivia. American Journal of Physical Anthropology, 136(4), 478-484.

Mikulski, R. (2007). Cross Bones burial ground summary. https://www.museumoflondon.org.uk/collections/other-collection-databases-and-libraries/centrehuman-bioarchaeology/osteological-database/post-medieval-cemeteries/cross-bones-postmedieval. Accessed November 2016.

Miles, A. \& Conheeney, J. (2005). A Post-medieval population from London: Excavations in the St Bride's Lower Churchyard 75-82 Farringdon Street, City of London. London (Unpublished).

Moorrees, C. F. A. Fanning, E. A., \& Hunt, E. E. (1963a). Formation and Resorption of Three Deciduous Teeth in Children. American Journal of Physical Anthropology, 21(2), 205-213.

Moorrees, C. F. A. Fanning, E. A. \& Hunt, E. E. (1963b). Age Variation of Formation Stages for Ten Permanent Teeth. Journal of Dental Research, 42(6), 1490-1502.

Mortier, G. R. \& Vanden Berghe, W. (2012). Genomics, Epigenetics and Growth. In N. Cameron and B. Bogin (Eds.) Human Growth and Development (pp. 153-172). London: Elsevier.

Museum of London (2015). Broadgate (Post-Medieval) cemetery summary. https://www.museumoflondon.org.uk/collections/other-collection-databases-and-libraries/centrehuman-bioarchaeology/osteological-database/post-medieval-cemeteries/broadgate-postmedieval. Accessed November 2016.

Newman, S. L. \& Gowland, R. L. (2017). Dedicated Followers of Fashion? Bioarchaeological Perspectives on Socio-Economic Status, Inequality, and Health in Urban Children from the Industrial Revolution ( $18^{\text {th }}-19^{\text {th }}$ Century) England. International Journal of Osteoarchaeology, 27(2), 217-229. 
Nicholas, S. \& Steckel, R. H. (1991). Heights and living standards of English workers during the early years of industrialization, 1770-1815. Journal of Economic History, 51(4), 937-957.

Nitsch, E.K., Humphrey, L.T., \& Hedges, R. E. M. (2011). Using stable isotope analysis to examine the effect of economic change on breastfeeding practices in Spitalfields, London, UK. American Journal Physical Anthropology, 146(4), 619-628.

Oestreich, A. E. (2008). Growth of the Pediatric Skeleton: A Primer for Radiologists. New York: Springer.

Ogden, A. R., Pinhasi, R., \& White, W. J. (2007). Gross enamel hypoplasia in molars from subadults in a 16th-18th century London graveyard. American Journal of Physical Anthropology, 133(3), 957-966.

Oxford University News (2014). Babies born to health mums are strikingly similar in size worldwide. http://www.ox.ac.uk/news/2014-07-07-babies-born-healthy-mums-are-strikinglysimilar-size-worldwide. Accessed August 2018.

Perry, M. A. (2006). Redefining childhood through bioarchaeology: Toward an archaeological and biological understanding of children in Antiquity. Archaeological Papers of the American Anthropological Association, 15(1), 89-111.

Phelan, J. C., Link, B. G., \& Tehranifar, P. (2010). Social conditions as fundamental causes of health inequalities: theory, evidence, and policy implications. Journal of Health and Social Behaviour, 51, S28-S40.

Pinhasi, R., Shaw, P., White, B., \& Ogden, A. R. (2006). Morbidity, rickets and long-bone growth in post-medieval Britain - a cross-population analysis. Annals of Human Biology, 33(3), 372-398.

Pomeroy, E., Stock, J. T., Stanojevic, S., Miranda, J. J., Cole, T. J., \& Wells, J. C. K. (2012). Trade-Offs in Relative Limb Length among Peruvian Children: Extending the Thrifty Phenotype Hypothesis to Limb Proportions. PloS One, 7(12), 1-10.

Redfern, R. (2003). Sex and the City: A biocultural investigation into female health in Roman Britain. In G. Carr, E. Swift and J Weekes (Eds.) TRAC 2002 Proceedings of the Twelfth Annual Theoretical Roman Archaeology Conference. Oxford: Oxbow Books. 
Reitsema, L.J. \& McIlvaine, B. K. (2014). Reconciling "stress" and "health" in physical anthropology: What can bioarchaeologists learn from the other subdisciplines? American Journal of Physical Anthropology, 155(2), 181-185.

Richardson, S. S., Daniels, C. R., Gillman, M. W., Golden, J., Kukla, R., Kuzawa, C., \& RichEdwards, J. (2014). Society: don't blame the mothers. Nature News, August $13^{\text {th }} 2014$.

Robb, J., Bigazzi, R., Lazzarini, L., Scarsini, C., \& Sonego, F. (2001). Social 'status' and biological 'status': a comparison of grave goods and skeletal indicators from Pontecagnano. American Journal of Physical Anthropology, 115(3), 213-222.

Robertson, T., Batty, G. D., Der, G., Fenton, C., Shiels, P. G., \& Benzeval, M. (2013). Is socioeconomic status associated with biological aging as measured by Telomere Length? Epidemiological Review, 35, 98-111.

Rogers, A. (1997). Vulnerability, health and healthcare. Journal of Advanced Nursing, 26(1), 6572.

Said-Mohamed, R., Pettifor, J. M., \& Norris, S. A. (2018). Life History theory hypotheses on child growth: Potential implications for short and long-term child growth, development and health. American Journal of Physical Anthropology, 165(1), 4-19.

Sánchez Romero, M. (2017). Landscapes of Childhood: Bodies, Places and Material Culture. Childhood in the Past, 10(1), 16-37.

Sandman, C. A., Glynn, L. M., \& Davis, E.P. (2016). Neurobehavioral Consequences of Fetal Exposure to Gestational Stress. In N. Reissland and B. S. Kisilevsky (Eds.) Fetal Development (pp. 29-265). Switzerland: Springer International Publishing.

Satterlee Blake, K. A. (2018). The Biology of the Fetal Period: Interpreting Life from Fetal Skeletal Remains. In S. Han, T. K. Betsinger, and A. B. Scott (Eds.) The Anthropology of the Fetus (pp. 34-58). New York: Berghahn Books.

Saunders, S. R. \& Hoppa, R. D. (1993). Growth Deficit in Survivors and Non-Survivors: Biological Mortality Bias in Subadult Skeletal Samples. Yearbook of Physical Anthropology, 36(S17), 127-151.

Schell, L. M. (1997). Culture as a Stressor: A Revised Model of Biocultural Interaction. American Journal of Physical Anthropology, 102(1), 67-77. 
Scheuer, L. \& Black, S. (2000a). Developmental Juvenile Osteology. London: Academic Press.

Scheuer, L. \& Black, S. (2000b). Development and Ageing of the Juvenile Skeleton. In M. Cox and S. Mays (Eds.) Human Osteology in Archaeology and Forensic Science (pp. 9 - 21). London: Greenwich Medical Media Ltd.

Scheuer, L. Musgrave, J. H. \& Evans, S. P. (1980). The estimation of late fetal and perinatal age from limb bone length by linear and logarithmic regression. Annals of Human Biology, 7(3), 257-265.

Schofield, J. \& Maloney, C. (1998). Archaeology in the City of London, 1907-1991: A guide to records of excavations by the Museum of London and its predecessors. London: Museum of London.

Sinclair, D. (1985). Human Growth After Birth. Oxford: Oxford University Press. Slack, J. M. W. (1991). From Egg to Embryon: Regional Specification in Early Development. Cambridge: Cambridge University Press.

Snoddy, A. M. E., Buckley, H. R., Elliott, G. E., Standen, V. G., Arriaza, B. T., \& Halcrow, S. E. (2018). Macroscopic features of scurvy in human skeletal remains: A literature synthesis and diagnostic guide. American Journal of Physical Anthropology, 167(4), 876-895.

Steckel, R. H. (2009). Heights and human welfare: recent developments and new directions. Explorations in Economic History, 46, 1-23.

Stinson, S. (2000). Growth variation: biological and cultural factors. In S. Stinson, B. Bogin, R. Huss-Ashmore, and D. H. O'Rourke (Eds.) Human biology: an evolutionary and biocultural perspective (pp. 434-438). New York: Wiley-Liss.

Storey, R. (1992). Preindustrial urban lifestyle and health. MASCA Research Papers in Science and Archaeology, 9, 33-41.

Tanner, J. M. (1978). Foetus Into Man: Physical Growth from Conception to Maturity. London: Open Books Publishing Ltd.

Thorsell, A. \& Nätt, D. (2016). Maternal stress and diet may influence affective behaviour and stress-response in offspring via epigenetic regulation of central peptidergic function. Environmental Epigenetics, 2(3), 1-10. 
Utczas, K., Muzsnai, A., Cameron, N., Zsakai, A., \& Bodzsar, E. B. (2017). A comparison of skeletal maturity assessed by radiological and ultrasonic methods. American Journal of Human Biology, 29(4), 1-7.

Wadhwa, P. D., Entringer, S., Buss, C., \& Lu, M. C. (2011). The Contribution of Maternal Stress to Preterm Birth: Issues and Considerations. Clinics in Perinatology, 38(3), 351-384.

World Health Organization (2018). Global Health Observatory (GHO) Data; Infant Mortality. http://www.who.int/gho/child_health/mortality/neonatal_infant_text/en/. Accessed August 2018.

Wilkie, L. A. (2013). Expelling frogs and binding babies: conception, gestation and birth in nineteenth-century African-American midwifery. World Archaeology, 45(2), 272-284.

Winick, M., Brasel, J. A., \& Rosso, P. (1972). Nutrition and Cell Growth. In M. Winick (Ed.) Nutrition and Development (pp. 49-98). London: John Wiley \& Sons Inc. 